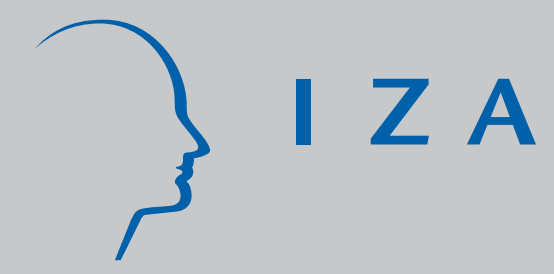

IZA DP No. 1178

What Is Left to Residual Claimants?

The Empirics of Income Reported by Entrepreneurs and Workers

\author{
Panu Poutvaara \\ J uha Tuomala \\ J une 2004
}




\title{
What Is Left to Residual Claimants? The Empirics of Income Reported by Entrepreneurs and Workers
}

\author{
Panu Poutvaara \\ CEBR, CESifo \\ and IZA Bonn
}

Juha Tuomala

VATT

\section{Discussion Paper No. 1178 \\ June 2004}

\author{
IZA \\ P.O. Box 7240 \\ 53072 Bonn \\ Germany \\ Phone: $+49-228-3894-0$ \\ Fax: +49-228-3894-180 \\ Email: iza@iza.org
}

Any opinions expressed here are those of the author(s) and not those of the institute. Research disseminated by IZA may include views on policy, but the institute itself takes no institutional policy positions.

The Institute for the Study of Labor (IZA) in Bonn is a local and virtual international research center and a place of communication between science, politics and business. IZA is an independent nonprofit company supported by Deutsche Post World Net. The center is associated with the University of Bonn and offers a stimulating research environment through its research networks, research support, and visitors and doctoral programs. IZA engages in (i) original and internationally competitive research in all fields of labor economics, (ii) development of policy concepts, and (iii) dissemination of research results and concepts to the interested public.

IZA Discussion Papers often represent preliminary work and are circulated to encourage discussion. Citation of such a paper should account for its provisional character. A revised version may be available on the IZA website (www.iza.org) or directly from the author. 


\section{ABSTRACT \\ What Is Left to Residual Claimants? The Empirics of Income Reported by Entrepreneurs and Workers*}

Using Finnish panel data, we study how entrepreneurs differ from workers in education and income dynamics. We find that workers have higher median income in all educational groups. Without additional controls, entrepreneurs have higher average income with all but undergraduate level of education. However, random effects and matching models suggest that entrepreneurs have lower incomes. We also analyze those who changed careers. Those with higher level of education are more likely to switch from entrepreneurship to workers, while education does not explain, in a statistically significant level, switching from being worker to entrepreneurship.

JEL Classification: J24, J31, C23

Keywords: entrepreneurs, workers, Finnish labor market, education

Corresponding author:

Panu Poutvaara

CEBR

Langelinie Allé 17

2100 Copenhagen

Denmark

Email: panu.poutvaara@cebr.dk

\footnotetext{
* An earlier version of this paper was presented at IZA research seminar in February 2004, and we greatly benefited from comments there. We also thank Axel Dreher, Martin Junge, Uli Kaiser, Vesa Kanniainen, Jaakko Kiander, Nikolaj Malchow-Møller, Heikki Räisänen, Bertel Schjerning, and Tuomas Takalo for helpful comments. The Statistics Finland has constructed the data from several administrative registers and other data bases.
} 
"The whole of the advantages and disadvantages of the different employments of labour and stock must, in the same neighborhood, be either perfectly equal or continually tending to equality." Adam Smith, The Wealth of Nations, Book I, Chapter X.

\section{Introduction}

Economic theory predicts that choices, including that of occupation, are made in order to maximize the expected utility. Already Adam Smith noted that, in a society with free occupational choice, if in a given location "there was any employment evidently either more or less advantageous than the rest, so many people would crowd into it in the one case, and so many would desert it in the other, that its advantages would soon return to the level of other employments." When people dislike risks, riskier occupation must, ceteris paribus, offer a higher expected income.

Entrepreneurship is a fundamentally different occupational choice than most salaried jobs. Apart from unemployment risk, workers typically enjoy a career path associated with a low level of income uncertainty. Entrepreneurs, on the other hand, are by definition residual claimants. Their income derives from uncertain profits. Even more, entrepreneurs often need to accept a considerable wealth risk, using their private wealth as a collateral for loans needed to finance business projects. Knight (1921) even defines entrepreneurship as fundamentally risk-bearing, accepting uninsurable possibility of failure in exchange for a compensation in the form of expected profits. Bearing risks can then be interpreted as a factor of production, combined with labor and capital in firms.

Research on entrepreneurship again gained momentum in the late 1970s. ${ }^{1}$ Lucas (1978) showed that ability differences may explain differences in enterprise size and growth. Kihlström and Laffont (1979) suggested that less risk-averse agents become entrepreneurs. As people are typically risk-averse, leaving lottery aside, an economist would then expect that entrepreneurship should offer some compensation for these risks, either in form of higher expected income or some non-monetary benefits. These non-monetary benefits may derive from independence associated with entrepreneurship, being one's own boss. On the other hand, non-monetary aspects of entrepreneurship need not be primarily positive. Whereas workers are able to leave their job behind during holidays, entrepreneurs often do not have that option, or exercising it would be much more costly. Entrepreneurs generally work longer hours and have shorter holidays than most workers. (Uusitalo 2001) Taking sabbatical may even amount to closing down the business. Moskowitz and Vissing-Jørgensen (2002) also find that in the United States, returns to private equity are not larger than returns to public equity. They report that about $75 \%$ of all private equity is owned by households for whom

\footnotetext{
${ }^{1}$ Ilmakunnas and Kanniainen (2001) provide a thorough survey on literature analyzing entrepreneurship, as well as empirical evidence on the effects of economic policy on entrepreneurship across OECD countries.
} 
it constitutes at least half of their total net worth. They suggest as alternative explanations for this puzzle the presence of large nonpecuniary benefits from investment in privately controlled company, a preference for skewness as well as the possibility of overconfidence.

In this paper, we aim to answer what observable characteristics explain the income of entrepreneurs, and how this process differs from that of workers. By entrepreneurs we mean residual claimants, whether they employ other persons in their firm, or are self-employed. Data on mandatory pension contributions allows us to distinguish whether a given person has earned more income as self-employed or worker. We estimate income equations separately for workers and entrepreneurs in order to find out to what extent education, gender, and age explain the variation in income, and whether workers and entrepreneurs exhibit systematic differences. Our data set consists of micro level panel data covering the period 1993-1997. The choice of the time period is determined by data, arising from not all capital income being included in the tax data before the year 1993, and the classification of education having changed in 1998. The sample of 350,000 individuals originates from Employment Statistics and other data bases.

Earlier, Uusitalo (2001) has analyzed the determinants of self-employment in Finland. He uses data on psychological tests, indicating that those becoming entrepreneurs are less risk-averse. Our focus is different, as we do not aim to answer who becomes entrepreneur in the first place, but how the incomes of entrepreneurs and workers of given observed characteristics differ. Our approach relying on microdata is also complementary to Ilmakunnas and Kanniainen (2001), who find evidence supporting the Knightian view on entrepreneurship from OECD cross-country macrodata.

Kangasharju and Pekkala (2002) found that the business cycle affects the relative closure rates of firms run by self-employed with any level of education. Self-employed with higher education have lower exit-probability during bust and higher in the upturn. This results from two facts. First, running a small firm is argued to be a less attractive choice to wage work for highly educated due to the lower earnings prospects, less stable stream of earnings and the tradition of working in large firms. Second, self-employed with higher education have a higher outside demand for their labor than the less educated during an economic boom. However, Kangasharju and Pekkala don't estimate earnings for workers and entrepreneurs with different characteristics.

Our paper is organized as follows. We present our data and stylized facts about income distribution in section 2. Section 3 presents our econometric analysis. We first estimate income equations with different levels of education, comparing entrepreneurs to workers using both fixed effects and random effects models. We then focus on those who stayed as workers or entrepreneurs over the whole time period. Then we present logit model of career changes, and finally a matching model. Section 4 concludes. 


\section{Theory and Stylized Facts}

\subsection{Occupational Choice and Expected Utility}

Already Roy (1951) modelled sectorial choice so that people form expectations of their earnings in the alternative sectors, then choosing the one offering a higher expected utility. As we observe only choices made, entrepreneurs and workers are likely to differ in some unobserved characteristics in addition to observed ones. This implies that we cannot assume that the income that someone having chosen entrepreneurship would have earned as a worker is even in expected value equal to that of those with same observed characteristics and having chosen a career as worker. Therefore, we will estimate earnings functions separately for workers and entrepreneurs. This allows us to compare the effects of education, gender, age, and other characteristics on earnings in the two occupations. Such differences reveal important characteristics of these two occupational choices. For example, we can expect that the observed characteristics would explain a smaller fraction of the earnings of entrepreneurs than that of workers. This would result from the presence of unobserved entrepreneurial talent. The difference in the share of the variance explained by earnings equations would then be suggestive of the relative importance of unobservable characteristics, including entrepreneurial talent. Part of it could also reflect the larger variance of income by entrepreneurs as residual claimants. We also use matching models to estimate whether the entrepreneurs are compensated for their higher income risks in the form of higher average income.

\subsection{Data}

The empirical analysis is based on micro level panel data covering the period 1993-1997. The data was constructed by Statistics Finland. The sample on 350,000 individuals were drawn from Employment Statistics. The data covers all individuals aged 12-75 in 1997 with permanent residence in Finland. The Statistics Finland has constructed the data by combining information from several administrative registers and other data bases. For example, information on individuals' employment have origins in the registers of the Ministry of Labour and information on individuals' income in the registers of the tax administration. The data is widely used in Finnish labor market studies. Among others Hämäläinen (2002) evaluated the impact of selective employment measures on the subsequent migration behavior of the participants.

The definition of occupational status is based on activities during the last week or working day of the year, as well as information on annual income. First of all, those being in military or civil service, students or retired during the last week of the year are defined to be outside of labor force. Of the remaining population, those registered as unemployed job searchers during the last working day of the year are counted as unemployed. Of the remaining population, those having either an employment contract or contributing towards self-employed persons' pension during the last week of the year are counted as employed. The employed are divided into workers and entrepreneurs according to in which category 
they have received more income. The distinction between the two types of income is based on mandatory pension contributions, which distinguish between income earned as worker and that earned as self-employed/entrepreneur. ${ }^{2}$

We also divide people into four educational categories. The lowest category is basic education or less, corresponding to at most 10 years of schooling. This suggests only obligatory schooling, as comprehensive school consists of 9 obligatory classes and an optional 10th class, most often taken by those unable to continue directly to high school or vocational education. The second category is high school or vocational education, implying in total 10-12 years of schooling. In Finland, most pupils take high school (and matriculation exam) in three years. Vocational education includes, e.g., basic nurses, nurses, commercial school graduates, clerks, and artisans. The third category, undergraduate education, includes those with only a Bachelor degree in university, as well as technicians, engineers and specialist nurses. Typically, obtaining education in this category takes 13 to 15 years. Finally, graduate education includes those with a Master's degree or more, and lasting 16 years or more. (Kyyrä 1999, p. 23)

The data contains information on each individual's age, gender, education, home municipality, occupational status and industry. There is also annual information on individuals' earned income, income from entrepreneurship, capital income and unemployment benefits. By combining these incomes we find out annual income.

\subsection{Stylized Facts}

Our sample contains 6,748 entrepreneurs and 73,692 wage earners working in any sector except agriculture, and aged at least 30 years in 1993 and at most 50 years in 1997. Agriculture is excluded due to its special feature of being almost an exclusively inherited rather than chosen occupation. Including agriculture could then bias the estimates of entrepreneurial earnings. We summarize our data in Tables 1 and 2 .

Table 1. Number of entrepreneurs and workers aged 34 to 50 in 1997

\begin{tabular}{|l|l|l|}
\hline & Workers & Entrepreneurs \\
\hline Total number & 73,692 & 6,748 \\
(of which females) & 37,528 & 2,222 \\
\hline Basic education or less & 16,093 & 1,892 \\
\hline High school or vocational education & 40,763 & 3,914 \\
\hline Undergraduate education & 9,330 & 485 \\
\hline Graduate education & 7,506 & 457 \\
\hline
\end{tabular}

\footnotetext{
${ }^{2}$ Those who are not in military of civil service, students, retired or unemployed during the last week of the year and do not have a labor contract or entrepreneurial insurance in force during the last week of the year are counted as workers or entrepreneurs if their annual labor or entrepreneurial income exceeds a given threshold.
} 
The share of entrepreneurs of those who are either workers or entrepreneurs is $8 \%$, ranging from only $5 \%$ of those with undergraduate education to $11 \%$ among those with basic education or less. In Table 2, we present average and median reported income for workers and entrepreneurs belonging to the categories in Table 1.

Table 2. Average and median incomes in 1997

\begin{tabular}{|c|c|c|}
\hline & $\begin{array}{c}\text { Workers } \\
\text { average (median) }\end{array}$ & $\begin{array}{c}\text { Entrepreneurs } \\
\text { average (median) }\end{array}$ \\
\hline All & $24,700 \quad(21,700)$ & $26,500(18,600)$ \\
\hline (Females) & $20,600 \quad(19,100)$ & $19,100(14,100)$ \\
\hline Basic education or less & $20,600 \quad(19,500)$ & $23,900 \quad(18,800)$ \\
\hline High school or vocational education & $22,500 \quad(20,700)$ & $25,300 \quad(17,300)$ \\
\hline Undergraduate education & $28,700 \quad(25,500)$ & $28,200 \quad(21,200)$ \\
\hline Graduate education & $40,700 \quad(35,300)$ & $45,900 \quad(32,200)$ \\
\hline
\end{tabular}

The main findings can be summarized as:

Result 1. Controlling only for education, entrepreneurs have higher average income in each group apart from those with undergraduate education, while workers have higher median income in all groups.

We find that there is no systematic difference in the relative incomes between entrepreneurs and workers of different levels of education, apart from workers with undergraduate education having both higher average and median income than workers. To summarize differences in income distribution between workers and entrepreneurs, we graph the kernel density estimates of income of all workers and entrepreneurs with different levels of education as Figures 1 to 4 . In those figures, we have censored first incomes of zero and then one percent from the bottom and one percent from the top of both workers and entrepreneurs for each education group. Minimum income is then more than zero. ${ }^{3}$

Certain common characteristics of income distributions warrant a further comment. First of all, the income distribution of entrepreneurs is very close to being log-normal in all educational groups. The income distribution of workers, on the other hand, is much more narrow. A plausible explanation for this would arise from wage bargaining and unemployment benefits, both tending to narrow income differences. There are no corresponding mechanisms that would tend to change the income distribution of entrepreneurs. Second, the higher average incomes of entrepreneurs are driven by higher average capital income. The share of those receiving capital income varied for workers between $10 \%$ (basic education or less) and $28 \%$ (graduate education), and for entrepreneurs between $67 \%$ (undergraduate education) and $70 \%$ (basic education or less). Omitting those with zero capital income, median

\footnotetext{
${ }^{3}$ In Figures 1 to 4, minimum income appears to be negative. This results from that kernel density function attaches a small area around every observation, so that observations at zero result in the figure seeming to start to the left of that point.
} 


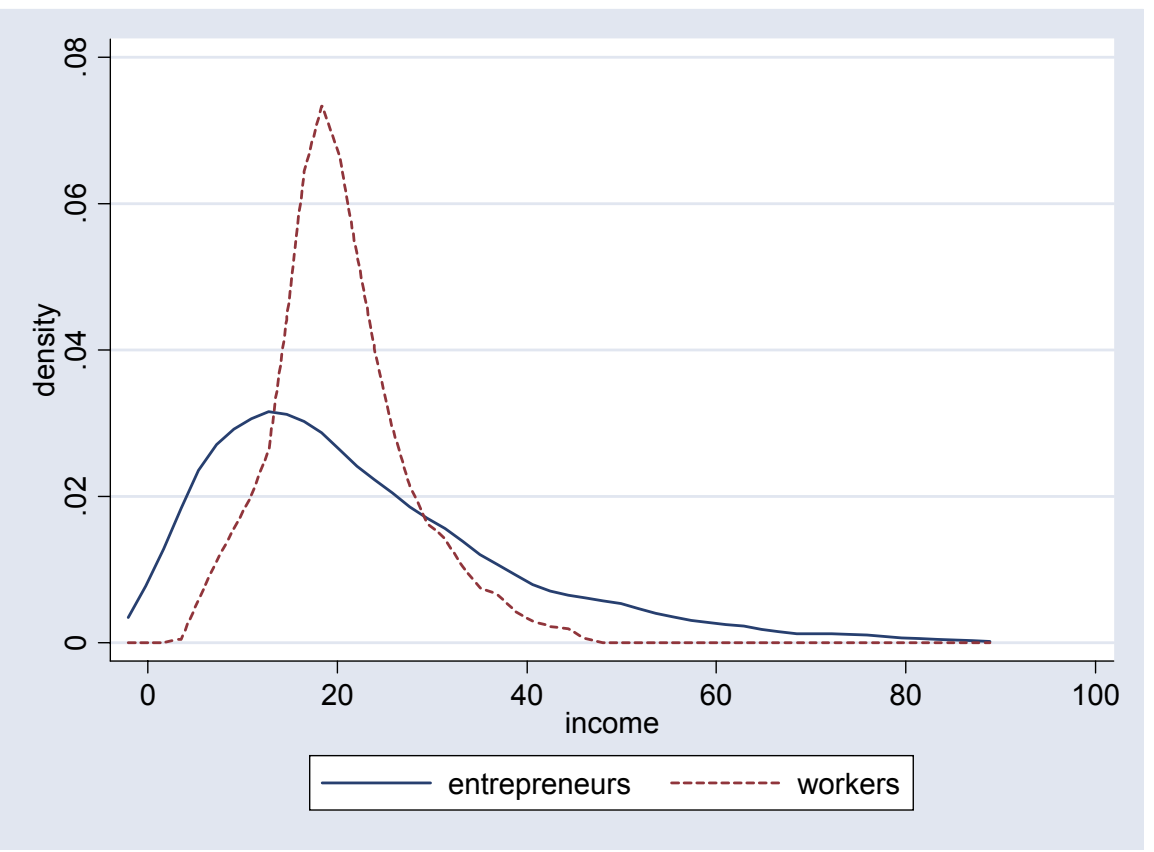

Figure 1: Incomes with basic education or less

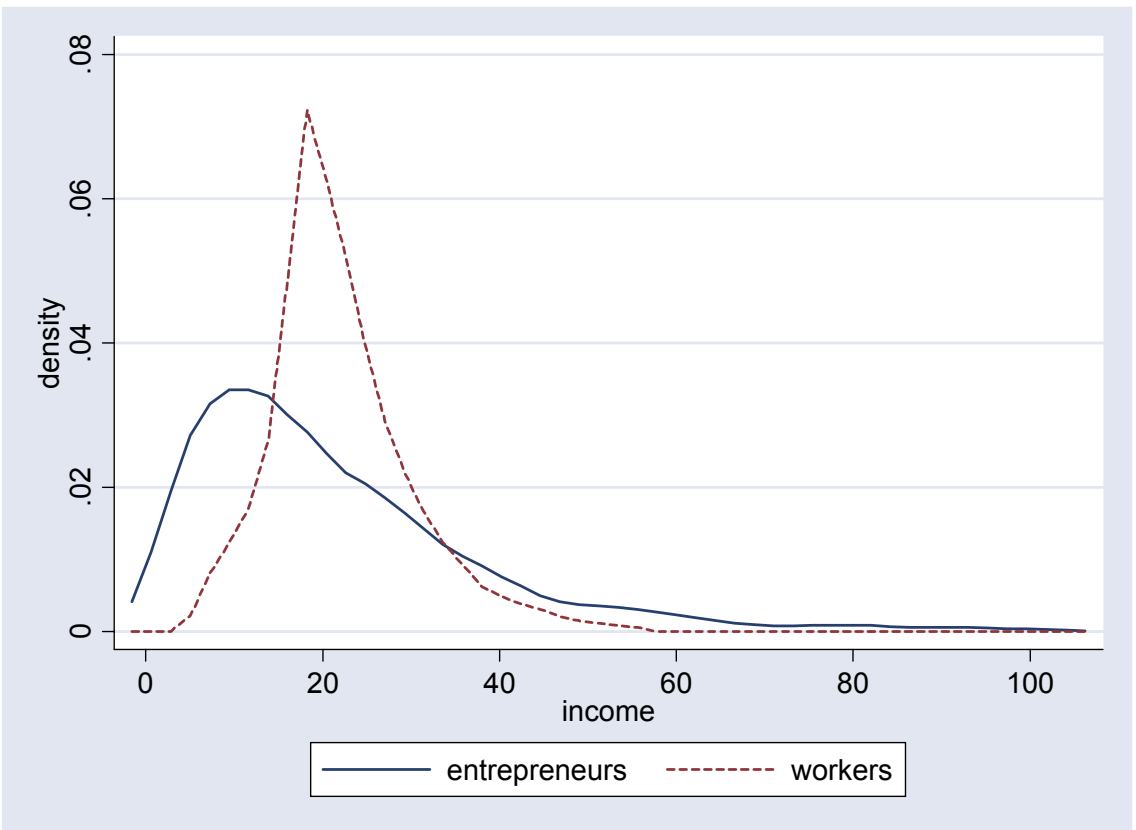

Figure 2: Incomes with high school or vocational education 


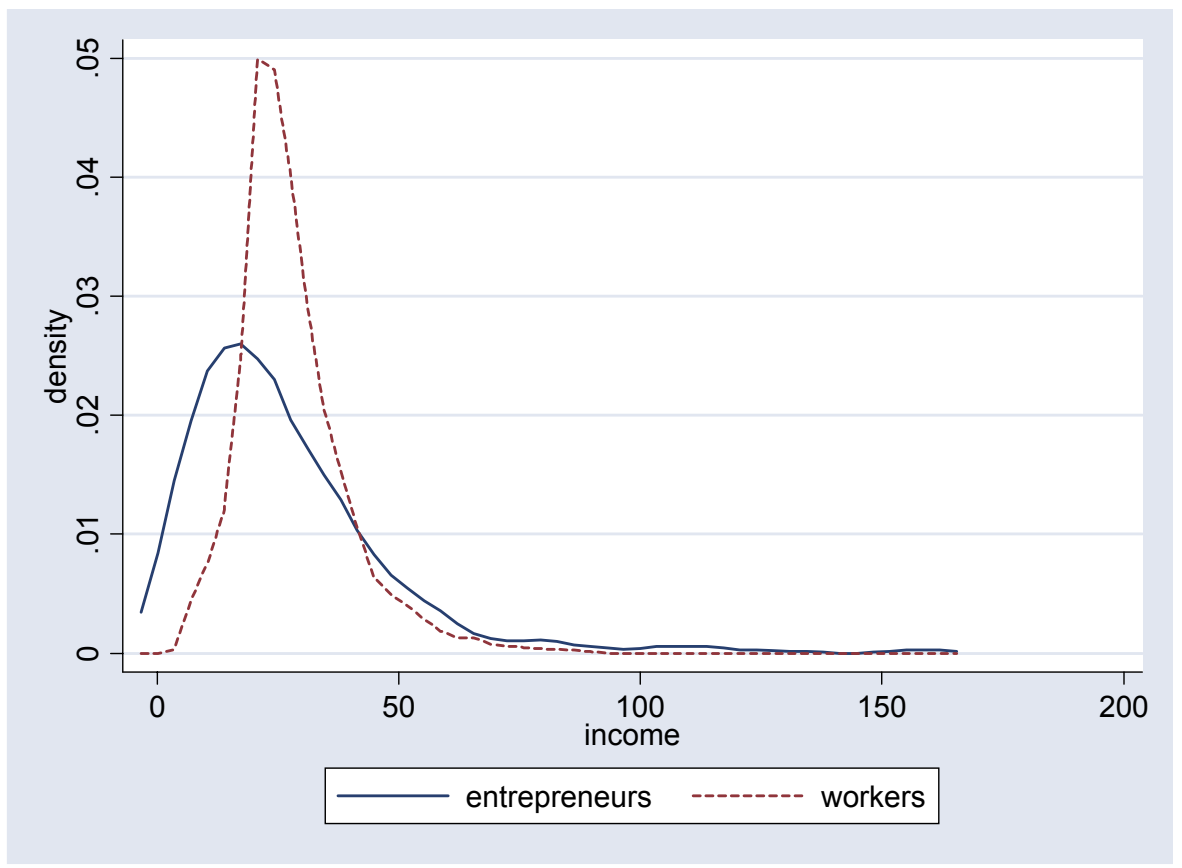

Figure 3: Incomes with undergraduate education

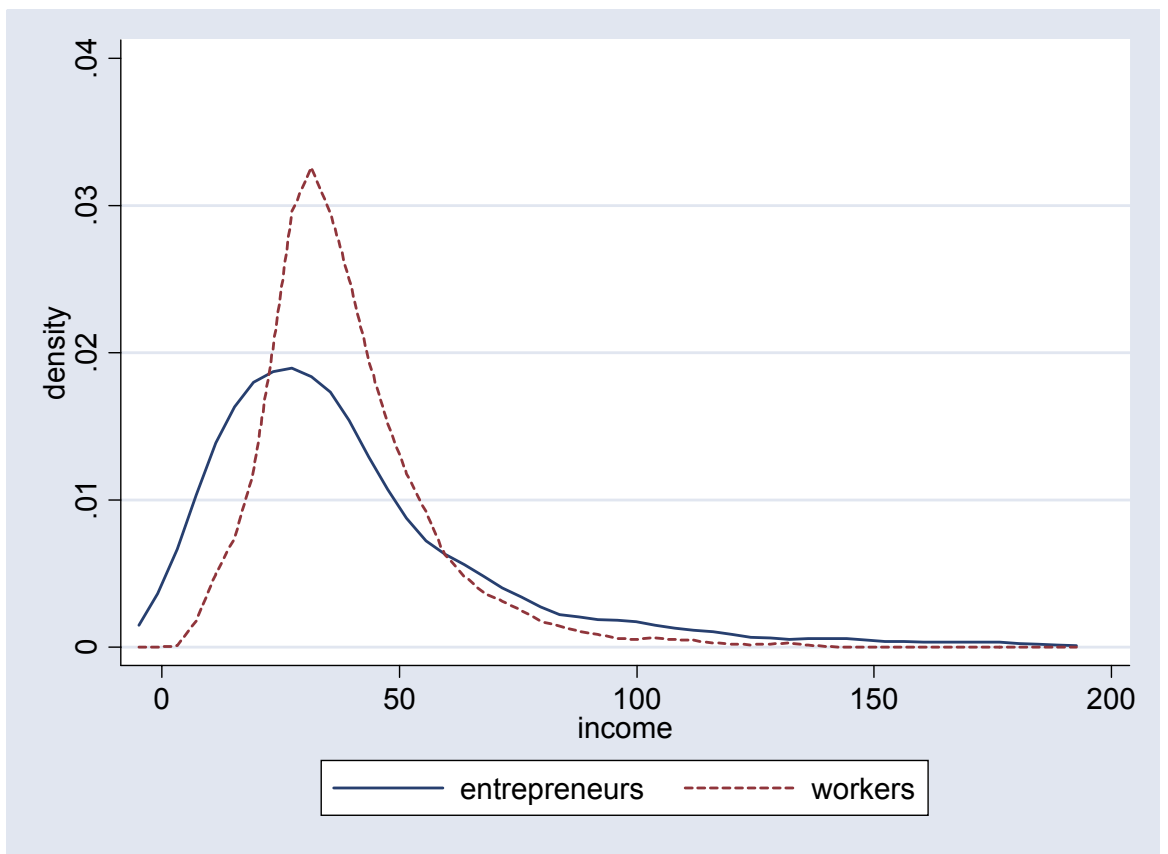

Figure 4: Incomes with graduate education 
income of those receiving it varied for workers between EUR 7,000 (basic education or less) and EUR 11,000 (graduate education), and for entrepreneurs between 14,000 (high school or vocational education) and EUR 18,000 (graduate education). The share of those receiving unemployment benefits varied for workers between $6 \%$ (graduate education) and $14 \%$ (high school or vocational education), and for entrepreneurs between $3 \%$ (graduate education) and $8 \%$ (undergraduate education).

Even though we observed a larger variance across entrepreneurs than across workers in a cross-section, what remains to evaluate is the magnitude of idiosyncratic risks. In this, we exploit the panel data. We calculate the average individual variance of log pre tax income. In the analysis, we add those with undergraduate and those with graduate level together due to the small sample size for entrepreneurs in those groups.

Table 3. Average variance of log pre tax incomes (1993-1997)

\begin{tabular}{|l|l|l|l|l|l|l|}
\hline & \multicolumn{2}{|c|}{$\begin{array}{c}\text { Basic education } \\
\text { or less }\end{array}$} & \multicolumn{2}{c|}{$\begin{array}{c}\text { High school or } \\
\text { vocational education }\end{array}$} & \multicolumn{2}{c|}{$\begin{array}{c}\text { Undergraduate or } \\
\text { graduate education }\end{array}$} \\
\hline Age: & workers & entrepreneurs & workers & entrepreneurs & workers & entrepreneurs \\
\hline $30-39$ & 0.012 & 0.191 & 0.015 & 1.385 & 0.015 & 1.098 \\
\hline $40-50$ & 0.011 & 0.155 & 0.007 & 0.177 & 0.006 & 0.058 \\
\hline
\end{tabular}

We can summarize the results as ${ }^{4}$

Result 2. Entrepreneurs have higher variance of their income across years than workers.

Higher variance of income of entrepreneurs is consistent with their role as residual claimants. ${ }^{5}$ Finally, we calculated the share of workers receiving also entrepreneurial income and of entrepreneurs receiving also wage income. While only a small minority of workers receive also entrepreneurial income above EUR 1,000, a substantial fraction of entrepreneurs received also wage income above EUR $1,000 .{ }^{6}$ A caveat to be kept in mind is that entrepreneurs are to a large extent able to decide themselves, how much income they take as wage income from their own company. Such decisions are likely to be driven by considerations to minimize tax.

\section{Econometric Analysis}

In this section, we estimate the effect of entrepreneurship on reported earnings. We start by a comprehensive analysis of those aged at least 30 in 1993 and at most 50 in 1997 using panel data models. We choose this age range in order to focus on people active in the labor

\footnotetext{
${ }^{4}$ Qualitative results are similar when analyzing those who were initially entrepreneurs (workers).

${ }^{5}$ There are 1,394 entrepreneurs aged 30-39 with high school or vocational education, and 205 with undergraduate or graduate education. These groups contain individuals with very high variances of log pre tax income, resulting in average variances of a higher order of magnitude than for older entrepreneurs.

${ }^{6} 4 \%$ of workers (20\% of entrepreneurs) earning at least EUR 6,000 in their main activity received also at least EUR 1,000 entrepreneurial income (wage income).
} 
market. A larger share of those in their 20s are studying, while retirement typically sets in only after the age of 50. The choice of time period is determined by data, arising from not all capital income being included in the tax data before the year 1993, and the classification of education having changed in 1998.

We first estimate the effect of entrepreneurship on reported income, contrasting fixed effects and random effects models. In the second subsection, we focus only on those who stayed as either workers or entrepreneurs over the whole five-year period, and in the third subsection we compare those who stayed as workers or entrepreneurs to those who changed careers. Finally, we evaluate income differences between entrepreneurs and workers utilizing propensity score matching.

\subsection{Whole Workforce}

We estimate random effects and fixed effects models for those aged 30 to 50 over the whole time period 1993 to 1997. Also individuals in other labor market states than entrepreneurs or workers are included. Models are estimated separately for different education levels including only those whose educational status remained same over the whole period. This avoids the problems that would arise from education being an endogenous variable, which may have different effects on workers and entrepreneurs, and is likely to be correlated with unobserved characteristics that also affect the choice between being worker or entrepreneur. As earlier income is defined as the sum of earned income, consisting mainly of wages and salaries, entrepreneurial income, unemployment benefits and capital income. We use the notation

$$
\log (\text { income })_{i t}=X B+u_{i}+e_{i t} .
$$

That is, $u_{i}$ is fixed or random effect and $e_{i t}$ is the pure residual, for units $\mathrm{i}=1, \ldots, \mathrm{n}$ measured at times $\mathrm{t}=1993, \ldots, 1997$.

Random effects models suit better for the purpose of this study, because fixed effects model is estimated using time-series information of the data and we are also interested in cross-sectional information. Nonetheless, fixed effects models provide interesting additional information on those who change careers. Test statistics do not allow us to conclude which model would suit the data better statistically. ${ }^{7}$ Therefore, we report estimated income equations using both fixed and random effects models. In addition to the variables that we include in tables 4 and 5, we included a separate dummy for those not being workers or entrepreneurs in a given year, its interaction with gender dummy, constant, dummies for different age groups and interactions between occupational and year dummies. ${ }^{8}$

\footnotetext{
${ }^{7}$ We used Hausman test, which requires that the difference between two separately estimated covariance matrices is positive definite. This is not the case in our data.

${ }^{8}$ Complete estimation results are available upon request, as are results with between effects model and pooled OLS. Results for $\mathrm{F}$ test that all $u_{i}=0$ and for Breusch-Pagan chi2 test are all statistically significant at $1 \%$ level.
} 
Table 4 a. Estimation results with random effects

\begin{tabular}{llllc}
\hline & $\begin{array}{c}\text { Basic education } \\
\text { or less }\end{array}$ & $\begin{array}{c}\text { High school or } \\
\text { vocational education }\end{array}$ & $\begin{array}{c}\text { Undergraduate } \\
\text { education }\end{array}$ & $\begin{array}{c}\text { Graduate } \\
\text { education }\end{array}$ \\
\hline Female & $-0.218^{* * *}$ & $-0.276^{* * *}$ & $-0.355^{* * *}$ & $-0.314^{* * *}$ \\
Year & & & & \\
1994 & $0.011^{* * *}$ & $0.015^{* * *}$ & $0.019^{* * *}$ & $0.023^{* * *}$ \\
1995 & $0.053^{* * *}$ & $0.063^{* * *}$ & $0.054^{* * *}$ & $0.071^{* * *}$ \\
1996 & $0.082^{* * *}$ & $0.099^{* * *}$ & $0.091^{* * *}$ & $0.111^{* * *}$ \\
1997 & $0.098^{* * *}$ & $0.123^{* * *}$ & $0.110^{* * *}$ & $0.134^{* * *}$ \\
Entrepreneur & $-0.010^{* * *}$ & $-0.084^{* * *}$ & $-0.300^{* * *}$ & $-0.072^{* * *}$ \\
Entr. x Female & $-0.107^{* * *}$ & $-0.154^{* * *}$ & -0.031 & $0.059^{*}$ \\
\hline
\end{tabular}

* Significant at $10 \%$ level; ${ }^{* *}$ Significant at $5 \%$ level; ${ }^{* * *}$ Significant at $1 \%$ level Table 4 b. Test results

\begin{tabular}{lllll}
\hline & $\begin{array}{c}\text { Basic education } \\
\text { or less }\end{array}$ & $\begin{array}{c}\text { High school or } \\
\text { vocational education }\end{array}$ & $\begin{array}{c}\text { Undergraduate } \\
\text { education }\end{array}$ & $\begin{array}{c}\text { Graduate } \\
\text { education }\end{array}$ \\
\hline $\mathrm{R}^{2}$ (total) & 0.340 & 0.320 & 0.344 & 0.301 \\
$\mathrm{R}^{2}$ (Within) & 0.074 & 0.100 & 0.163 & 0.143 \\
$\mathrm{R}^{2}$ (Between) & 0.476 & 0.436 & 0.439 & 0.381 \\
$\rho$ & 0.544 & 0.512 & 0.505 & 0.546 \\
$\mathrm{~N}$ & 23094 & 52035 & 9243 & 7793 \\
\hline
\end{tabular}

Note: $\rho$ is fraction of variance due to $u_{i}$ 
Table 5 a. Estimation results with fixed effects

\begin{tabular}{lllll}
\hline & $\begin{array}{c}\text { Basic education } \\
\text { or less }\end{array}$ & $\begin{array}{c}\text { High school or } \\
\text { vocational education }\end{array}$ & $\begin{array}{c}\text { Undergraduate } \\
\text { education }\end{array}$ & $\begin{array}{c}\text { Graduate } \\
\text { education }\end{array}$ \\
\hline Year & & & & \\
1994 & $0.018^{* * *}$ & $0.023^{* * *}$ & $0.035^{* * *}$ & $0.038^{* * *}$ \\
1995 & $0.067^{* * *}$ & $0.080^{* * *}$ & $0.086^{* * *}$ & $0.101^{* * *}$ \\
1996 & $0.104^{* * *}$ & $0.127^{* * *}$ & $0.137^{* * *}$ & $0.155^{* * *}$ \\
1997 & $0.132^{* * *}$ & $0.163^{* * *}$ & $0.175^{* * *}$ & $0.196^{* * *}$ \\
Entrepreneur & $0.074^{* * *}$ & 0.002 & $-0.224^{* * *}$ & $-0.055^{*}$ \\
Entr. x Female & $-0.064^{* * *}$ & $-0.162^{* * *}$ & -0.064 & -0.035 \\
\hline
\end{tabular}

* Significant at $10 \%$ level; **Significant at $5 \%$ level; *** Significant at $1 \%$ level Table 5 b. Test results

\begin{tabular}{lllll}
\hline & $\begin{array}{c}\text { Basic education } \\
\text { or less }\end{array}$ & $\begin{array}{c}\text { High school or } \\
\text { vocational education }\end{array}$ & $\begin{array}{c}\text { Undergraduate } \\
\text { education }\end{array}$ & $\begin{array}{c}\text { Graduate } \\
\text { education }\end{array}$ \\
\hline $\mathrm{R}^{2}$ (total) & 0.297 & 0.268 & 0.252 & 0.215 \\
$\mathrm{R}^{2}$ (Within) & 0.079 & 0.106 & 0.168 & 0.148 \\
$\mathrm{R}^{2}$ (Between) & 0.442 & 0.398 & 0.335 & 0.298 \\
$\rho$ & 0.687 & 0.651 & 0.644 & 0.663 \\
$\mathrm{~N}$ & 23094 & 52035 & 9243 & 7793 \\
\hline
\end{tabular}

Our results can be summarized as:

Result 3. Random effects models suggest that entrepreneurs have lower incomes than workers with same analyzed characteristics with all levels of education.

Result 4. Fixed effects models suggest that those who change careers and have basic education or less (undergraduate or graduate education), earn more (less) as entrepreneurs. The incomes of those with high school or vocational education do not change, in average.

We also find that women with basic education have relatively lower income as entrepreneurs compared to being workers than men, while women with graduate education actually gain from entrepreneurship compared to men as entrepreneurs. ${ }^{9}$

\subsection{Workforce without Career Changes}

In this subsection we model log incomes for those whose occupational status was either worker or entrepreneur over the whole period 1993-1997. Individuals aged 30 to 50 are included also in this analysis. Once again same specifications tests are performed, with similar results. ${ }^{10}$

\footnotetext{
${ }^{9}$ We must take into account that the number of female entrepreneurs with graduate education is quite small.

${ }^{10}$ Only constants are omitted from tables. Complete estimation results are available upon request, as are results with between effects model and pooled OLS.
} 
Table 6 a. Estimation results for entrepreneurs (1993-1997)

\begin{tabular}{lll}
\hline & Fixed effects & Random effects \\
\hline Female & & $-0.419^{* * *}$ \\
Age & & \\
$36-40$ & $0.044^{*}$ & $0.069^{* * *}$ \\
$41-45$ & 0.009 & $0.071^{* * *}$ \\
$46-50$ & -0.034 & $0.053^{*}$ \\
Education & & \\
High school or vocational education & -0.020 & 0.004 \\
Undergraduate education & 0.145 & $0.200^{* * *}$ \\
Graduate education & 0.230 & $0.663^{* * *}$ \\
Year & & \\
1994 & $0.079^{* * *}$ & $0.073^{* * *}$ \\
1995 & $0.093^{* * *}$ & $0.082^{* * *}$ \\
1996 & $-0.029^{* *}$ & $-0.046^{* * *}$ \\
1997 & $0.069^{* * *}$ & $0.048^{* * *}$ \\
\hline
\end{tabular}

* Significant at $10 \%$ level; **Significant at $5 \%$ level; *** Significant at $1 \%$ level Table 6 b. Test results

\begin{tabular}{lll}
\hline & Fixed effects & Random effects \\
\hline $\mathrm{R}^{2}$ (total) & 0.021 & 0.068 \\
$\mathrm{R}^{2}$ (Within) & 0.009 & 0.009 \\
$\mathrm{R}^{2}$ (Between) & 0.029 & 0.092 \\
$\rho$ & 0.665 & 0.622 \\
$\mathrm{~N}$ & 4527 & \\
\hline
\end{tabular}

Note: $\rho$ is fraction of variance due to $u_{i}$ 
Table 7 a. Estimation results for workers (1993-1997)

\begin{tabular}{lll}
\hline & Fixed effects & Random effects \\
\hline Female & & $-0.327^{* * *}$ \\
Age & & \\
$36-40$ & $0.015^{* * *}$ & $0.051^{* * *}$ \\
$41-45$ & $0.013^{* * *}$ & $0.089^{* * *}$ \\
$46-50$ & $-0.009^{* *}$ & $0.095^{* * *}$ \\
Education & & \\
High school or vocational education & $0.041^{* * *}$ & $0.079^{* * *}$ \\
Undergraduate education & $0.169^{* * *}$ & $0.307^{* * *}$ \\
Graduate education & $0.242^{* * *}$ & $0.534^{* * *}$ \\
Year & & \\
1994 & $0.045^{* * *}$ & $0.038^{* * *}$ \\
1995 & $0.099^{* * *}$ & $0.085^{* * *}$ \\
1996 & $0.114^{* * *}$ & $0.120^{* * *}$ \\
1997 & $0.165^{* * *}$ & $0.139^{* * *}$ \\
\hline
\end{tabular}

Table 7 b. Test results

\begin{tabular}{lll}
\hline & Fixed effects & Random effects \\
\hline $\mathrm{R}^{2}$ (total) & 0.145 & 0.316 \\
$\mathrm{R}^{2}$ (Within) & 0.101 & 0.097 \\
$\mathrm{R}^{2}$ (Between) & 0.175 & 0.366 \\
$\rho$ & 0.773 & 0.691 \\
$\mathrm{~N}$ & 56099 & \\
\hline
\end{tabular}

In the entrepreneurs' fixed effects model education dummies are insignificant (table 6). In table 7 all education dummies are positive and significant including fixed effects coefficients. We use the levels of education as control variables when studying income differences between entrepreneurs and workers. As education is likely to be correlated with a missing variable of individual ability, the estimated coefficients in random effects models reflect their joint effect, and should not be interpreted as estimates about the effects of education. Although education has little "within" variability we can conclude from fixed effects models that workers gain from extra education more than entrepreneurs. This is reasonable because workers' salaries probably depend on formal education. Many firms in Finland pay increment when employee graduates. On the other hand entrepreneurs cannot (or they do not have to) demand salary increase although they obtain more education.

Result 5. Fixed effects models suggest that workers' income increases after they receive additional education, while there is no evidence of this kind of effect in the case of entrepreneurs. 
One caveat when interpreting Result 5 is that an increase in the income of workers need not necessarily reflect increased hourly earnings. It could be that those studying would work less. An increase in earnings after graduation could then arise already due to increased labor supply. We also see that workers have bigger coefficients of determination $\left(\mathrm{R}^{2}\right)$ than entrepreneurs. There are two complementary explanations for this. On the one hand, the role of entrepreneurs as residual claimants implies that they can be expected to have inherently higher randomness of income, thus contributing to lower explanatory power of estimators. On the other hand, lower coefficients of determination for entrepreneurs may reflect the missing variable of entrepreneurial talent.

\subsection{Career Changes}

In this section, we study who change their careers. We start by a descriptive analysis, and then study the explanatory power of a logit model of career changes. We separate four subgroups of the 18-64-year old population (1994-1997): (a) those who stayed as workers all years 1994 through 1997, (b) those who stayed as entrepreneurs all years 1994 through 1997, (c) those who were workers in 1994 and 1995 but became entrepreneurs in 1996 and 1997 and (d) those who were entrepreneurs in 1994 and 1995 but became workers in 1996 and 1997. We report in Table 8 the distribution of educational status in these four groups in 1994 and 1997.

Table 8: Educational shares in the four career paths in 1994 (in parentheses 1997)

\begin{tabular}{|l|l|l|l|l|}
\hline & Workers & Entrepreneurs & $\begin{array}{c}\text { Workers to } \\
\text { entrepreneurs }\end{array}$ & $\begin{array}{c}\text { Entrepreneurs } \\
\text { to workers }\end{array}$ \\
\hline Basic or less & $25(24)$ & $38(37)$ & $24(23)$ & $24(24)$ \\
\hline $\begin{array}{c}\text { High school } \\
\text { or vocational }\end{array}$ & $53(53)$ & $54(54)$ & $60(58)$ & $60(57)$ \\
\hline Undergraduate & $12(13)$ & $5(5)$ & $9(10)$ & $9(11)$ \\
\hline Graduate & $10(10)$ & $4(4)$ & $8(9)$ & $7(8)$ \\
\hline
\end{tabular}

Table 8 tells us that those switching from workers to entrepreneurs had in average lower education than those who stayed as workers. Especially high school or vocational education is typical for those who switched from workers to entrepreneurs. Those switching from entrepreneurs to workers had in average higher education than those who stayed as entrepreneurs. Their education, however, was still in average lower than that of those who were initially employed as workers.

Table 9 reports the share of those receiving unemployment benefits in 1995 and 1996 in different groups. We find that the incidence of unemployment is much higher among those switching between the two occupational categories than among those staying in one category. 
Table 9: Shares of those receiving unemployment benefits in 1995 (1996)

\begin{tabular}{|l|l|l|l|l|}
\hline & Workers & Entrepreneurs & $\begin{array}{c}\text { Workers to } \\
\text { entrepreneurs }\end{array}$ & $\begin{array}{c}\text { Entrepreneurs } \\
\text { to workers }\end{array}$ \\
\hline Basic or less & $4(5)$ & $0(0)$ & $13(17)$ & $5(7)$ \\
\hline $\begin{array}{c}\text { High school } \\
\text { or vocational }\end{array}$ & $5(5)$ & $1(0)$ & $10(9)$ & $7(8)$ \\
\hline Undergraduate & $5(5)$ & $1(0)$ & $2(13)$ & $8(13)$ \\
\hline Graduate & $3(3)$ & $1(0)$ & $3(15)$ & $3(2)$ \\
\hline
\end{tabular}

We summarize the results as

Result 6. Those who stay as workers have higher education than those who stay as entrepreneurs. The distribution of educational status among those who switched from entrepreneurs to workers is about the same as that of those making the opposite change.

Result 7. Apart from entrepreneurs with graduate education who become workers, career changes in either direction are associated with higher incidence of unemployment than staying in either category.

Results in Table 9 suggest that career changes often result from unemployment, with the exception that entrepreneurs with graduate education who become workers have an even lower incidence of unemployment than those with graduate education who were initially workers. Apart from those with undergraduate education, a larger share of those switching from workers to entrepreneurs suffered from unemployment than in the group changing from entrepreneurs to workers. We present logit estimates for career changes in Tables 10.a and 10.b, controlling for education, age, gender, and industry of occupation in the year before career change. 
Table 10.a. Logit-estimates for career changes (entrepreneurs -> workers 1996)

\begin{tabular}{lll}
\hline & Coeff. & Robust std. err. \\
\hline Constant & $-1.333^{* * *}$ & 0.329 \\
Female & -0.104 & 0.129 \\
Age & $-0.043^{* * *}$ & 0.006 \\
& & \\
Education (ref= basic or less) & & \\
High school or vocational education & $0.232^{*}$ & 0.128 \\
Undergraduate education & $0.503^{* *}$ & 0.209 \\
Graduate education & $0.711^{* * *}$ & 0.218 \\
& & \\
Industry 1995 (reference manufacturing): & & \\
Construction industry & -0.248 & 0.211 \\
Commerce & -0.113 & 0.178 \\
Commercial life services & 0.169 & 0.197 \\
Other service and Finance & $-0.960^{* * *}$ & 0.290 \\
Transport & $-0.651^{* * *}$ & 0.232 \\
Public administration & 0.167 & 0.541 \\
Social- and health service & $-0.528^{*}$ & 0.310 \\
Unclassified or missing & $0.696^{* * *}$ & 0.199 \\
Correct predictions, \% & & \\
Pseudo $R^{2}$ & 62,4 & \\
N & 0.044 & \\
\hline
\end{tabular}

* Significant at $10 \%$ level; **Significant at $5 \%$ level; *** Significant at $1 \%$ level 
Table 10.b. Logit-estimates for career changes (workers -> entrepreneurs 1996)

\begin{tabular}{lll}
\hline & Coeff. & Robust std. err. \\
\hline Constant & $-4.238^{* * *}$ & 0.258 \\
Female & $-0.581^{* * *}$ & 0.112 \\
Age & $-0.032^{* * *}$ & 0.005 \\
& & \\
Education (ref= basic or less) & & \\
High school or vocational education & 0.017 & 0.123 \\
Undergraduate education & -0.114 & 0.191 \\
Graduate education & 0.025 & 0.202 \\
& & \\
Industry 1995 (reference manufacturing): & & \\
Construction industry & $0.748^{* * *}$ & 0.185 \\
Commerce & $0.745^{* * *}$ & 0.150 \\
Commercial life services & $0.839^{* * *}$ & 0.165 \\
Other service and finance & $0.465^{* *}$ & 0.201 \\
Transport & $0.385^{* *}$ & 0.182 \\
Public administration & $-0.909^{* * *}$ & 0.268 \\
Social- and health service & $-0.660^{* *}$ & 0.271 \\
Unclassified or missing & $2.218^{* * *}$ & 0.239 \\
Correct predictions, \% & & \\
Pseudo $R^{2}$ & 61.0 & \\
N & 0.050 & \\
The & 103244 & \\
\hline
\end{tabular}

The share of entrepreneurs changing career to become workers is increasing in the level of education. Entrepreneurs in other service and finance, transport and social and health service change career less likely than entrepreneurs in manufacturing.

Female workers change career to entrepreneur less often than males. Education has no effect on switching career to entrepreneur. Workers in construction industry, commerce, commercial life services, other service and finance, and transport change career more than workers in manufacturing while workers in public administration and social and health service change career less likely than workers in manufacturing.

\subsection{Matching Application}

In this section we evaluate income differences between entrepreneurs and workers utilizing propensity score matching (see Rosenbaum and Rubin 1983). The propensity score is a number (indicator) which depicts the conditional probability of being assigned to a particular treatment. Propensity score replaces a collection of several characteristics with one number based on these characteristics. Propensity score matching allows to evaluate the Average Effect of Treatment on the Treated (ATT). In our case, the aim is to estimate the effect of 
entrepreneurship on income. Therefore, the "Treatment" is entrepreneurship, the "Treated" are entrepreneurs and the "Effect" is income difference between treated (entrepreneurs) and controls (workers with similar characteristics as entrepreneurs).

Probit model is estimated using predictor variables that influence both selection process to entrepreneurship as well as outcome of the interest (individual's income). We must also ensure the so-called common support, i.e. that there are both treated and non-treated individuals for each characteristic whose effect we want to compare. Dependent binary variable represents treated (entrepreneurs) and controls (workers) in our sample.

We use the 1997 population of 34-50 year old workers and entrepreneurs drawn from the data described in the section 2. In addition we focus on individuals with graduate or undergraduate level of education in the field of engineering or science. We have performed corresponding analysis to those with social sciences, business and law education, and the qualitative results are similar. ${ }^{11}$ Focusing analysis on a subgroup of population with a similar education helps to narrow down the role of unobserved ability differences. When both workers and entrepreneurs have completed similar education, it is likely that differences in their earnings reflect mostly compensating differentials for non-monetary aspects of different occupations as well as potentially compensation for income risks. In our sample, there were 334 entrepreneurs with graduate or undergraduate level of education as engineers and 4967 as workers.

The data is used to match these entrepreneurs and workers with higher education in the field of engineering and science and then compare their incomes (Leuven and Sianesi (2003). In the table 11 are reported estimation results for probit model explaining entrepreneurship. Most of the coefficients are significant and signs seem to be reasonable.

\footnotetext{
${ }^{11}$ These results are available upon request.
} 
Table 11 Probit estimates

\begin{tabular}{lll}
\hline & Coeff. & Std. err. \\
\hline Constant & $-2.410^{* * *}$ & 0.130 \\
Female & $-0.323^{* * *}$ & 0.106 \\
Age & & \\
$36-40$ & 0.064 & 0.116 \\
$41-45$ & $0.280^{* *}$ & 0.112 \\
$46-50$ & $0.480^{* * *}$ & 0.111 \\
& & \\
Education (ref = undergraduate education ) & & \\
Graduate education & $-0.218^{* * *}$ & 0.066 \\
& & \\
Industry (reference = manufacturing): & & \\
Construction industry & $0.928^{* * *}$ & 0.124 \\
Commerce & $1.118^{* * *}$ & 0.117 \\
Services & $1.025^{* * *}$ & 0.101 \\
Public administration and social- and health service & -0.201 & 0.165 \\
Transport and finance & $0.666^{* * *}$ & 0.156 \\
Unclassified & $2.616^{* * *}$ & 0.172 \\
& & \\
Log likelihood = -1000.9643 & & \\
Pseudo $R^{2}=0.1970$ & & \\
N = 5301 & & \\
\hline
\end{tabular}

* Significant at $10 \%$ level; **Significant at $5 \%$ level; *** Significant at $1 \%$ level

After propensity score is produced for each individual, controls are selected from workers. In other words, workers with similar characteristics as entrepreneurs compose control group. After this we can use different matching algorithms for the ATT estimation. The outcome of the interest is log income in the 1997 earned by entrepreneurs compared to log income of the workers with similar characteristics (ATT). In accordance with the matching theory, we also assume that our independent variables influence both the selection process and the outcome of the interest. ATT estimates and their standard errors are reported in table 12. 
Table 12. Estimation of ATT, dependent variable $=\log ($ income 1997)

\begin{tabular}{llll}
\hline Sample & Treated & Controls & Difference \\
\hline Unmatched & 3.094 & 3.551 & -0.457 \\
\hline \multicolumn{4}{l}{ Matching Method = Kernel } \\
ATT & 3.094 & 3.469 & -0.375 \\
Standard error & \multicolumn{3}{l}{0.118} \\
\hline Matching Method = Nearest Neighbor \\
ATT 3.094 & 3.485 & -0.390 \\
Standard error & \multicolumn{4}{l}{0.129} \\
\hline (standard errors are bootstrapped, 50 repetitions)
\end{tabular}

Two matching algorithms used produced statistically significant negative coefficients. The ATT point estimates differ somewhat, but the qualitative results are similar. Nearest Neighbor Matching produces a marginally smaller coefficient (Kernel $=-0.375$; Nearest Neighbor $=-0.390)$. This is due the fact that Nearest Neighbor Matching uses a more restricted and smaller sample than the Kernel Matching. We can, however, conclude that

Result 8. Entrepreneurs with higher education in the field of engineering and science have lower reported income than workers with similar characteristics.

We also estimated Ols model explaining log income in 1997. We used the same independent variables as in table 12 (probit model explaining entrepreneurship) and entrepreneur dummy. Entrepreneur dummy was negative and significant (-0.404) in Ols regression. This is somewhat smaller in absolute value than the effects obtained via matching methods.

\section{Conclusion}

In this paper, we have estimated the income equations for Finnish workers and entrepreneurs. Our aim was to explain how entrepreneurs differ from workers in observed characteristics, like education and income dynamics. In our sample, the share of entrepreneurs of the employed in different levels of education ranges from $5 \%$ of those with undergraduate education to 11 $\%$ of those with basic education or less. Those with undergraduate education are also the only group in which workers have higher average income than entrepreneurs. The median income is higher for workers in all educational groups. As we would expect, entrepreneurship is associated with considerably higher income risks than what workers face. Entrepreneurs also have a larger cross-sectional variance. Their income follows approximately log-normal distribution in all levels of education, while that of workers has a much narrower distribution. Random effect models suggest that entrepreneurs have lower incomes than workers, when controlling for other characteristics, like gender and age. Matching models, performed for those with engineering or science-based education and for those with social sciences, business and law education, also suggest that entrepreneurs would have lower incomes than workers 
with similar observed characteristics. We also find that the income dynamics of those who complete a higher education differ markedly between workers and entrepreneurs. For workers, an increase in educational status increases average income, while for entrepreneurs, it has no effect.

We also analyzed those who changed careers between being worker or entrepreneur. We found that those who stay as workers have in general higher education than entrepreneurs. The distribution of educational status among those who switched from entrepreneurs to workers is about the same as that of those making the opposite change. Logit estimates suggest that those with higher level of education are more likely to switch from entrepreneurship to workers, while education does not explain in a statistically significant level the probability of switching from being worker to entrepreneur. Fixed effects models suggest that those who change careers and have basic education or less, earn more as entrepreneurs. Those with undergraduate or graduate education earn in average less as entrepreneurs. The incomes of those with high school or vocational education do not change, in average. Apart from entrepreneurs with graduate education who become workers, career changes in either direction are associated with higher incidence of unemployment than staying as worker or entrepreneur.

\section{References}

[1] Hämäläinen, K., 2002, Unemployment, selective employment measures and interregional mobility of labour, Papers in Regional Science 81, 423-441.

[2] Ilmakunnas, P. and V. Kanniainen, 2001, Entrepreneurship, economic risks, and risk insurance in the welfare state: Results with OECD data 1978-93, German Economic Review 2, 195 - 218.

[3] Kangasharju, A. and S. Pekkala, 2002, The role of education in self-employment success, Growth and Change 33, 216-237.

[4] Kihlström, R. and J.-J. Laffont, 1979, A general equilibrium entrepreneurial theory of firm formation based on risk aversion, Journal of Political Economy 87, 719-748.

[5] Knight, F., 1921, Risk, uncertainty \& profit (The University of Chicago Press, Chicago/London 1971).

[6] Kyyrä, T., 1999, Post-unemployment wages and economic incentives to exit from unemployment, VATT Research reports 56.

[7] Leuven, E. and B. Sianesi, 2003, PSMATCH2: Stata module to perform full Mahalanobis and propensity score matching, common support graphing, and covariate imbalance testing, http://ideas.repec.org/c/boc/bocode/s432001.html. Version 1.2.3. 
[8] Lucas, R. Jr., 1978, On the size distribution of business firms, Bell Journal of Economics 9, 508-523.

[9] Moskowitz, T.J. and A. Vissing-Jørgensen, 2002, The returns to entrepreneurial investment: A private equity puzzle?, American Economic Review 92, 745-778.

[10] Roy, A., 1951, Some thoughts on the distribution of earnings, Oxford Economic Papers $3,135-146$.

[11] Rosenbaum, P. R. and D.B. Rubin, 1983, The central role of the propensity score matching in observational studies for causal effects, Biometrica 70, 41-50.

[12] Smith, A., 1965 [1776], An inquiry into the nature and causes of the wealth of nations (New York: Modern Library).

[13] Uusitalo, R., 2001, Homo entreprenaurus, Applied Economics 33, 1631-1638. 